\title{
PATTERN AND INJURY SEVERITY OF AUTO TRICYCLE "TOk-TOk" VEHICLES' ACCIDENTS: ONE YEAR PROSPECTIVE STUDY
}

\author{
Mofrih M. Hegazy and Shireen R. Slima \\ Forensic Medicine and Clinical Toxicology department, Faculty of Medicine, \\ Menoufia University \\ Corresponding author: \\ Mofrih Mohammad Hegazy \\ Assistant professor in Forensic Medicine and Clinical Toxicology department, Faculty \\ of Medicine, Menoufia University, Egypt. \\ E. mail: mofrihhegazy@yahoo.com \\ Mobile phone: 01012897290
}

\begin{abstract}
Background: Auto tricycles "Tok-Tok" are one of the widely used means of transportation in Egypt nowadays and there is an increased frequency of crash injuries related to their use in transportation. Objectives: This study was designed to assess pattern, injury severity level and factors associated with severity among auto tricycle accident victims who attended Menoufia University Hospitals from the first of January to the end of December 2018. Patients and Methods: This was one year hospital based prospective study conducted on 225 victims who sustained auto tricycle vehicles' accidents. Data about victims were collected including demographic profile (age, sex and residence); accident data (nature of the incident, type of injury and type of victim); clinical data (region of the body affected, type of lesion, severity of injury, treatment and outcome). Also, Injury severity Score (ISS) was calculated and cases were classified accordingly as having minor injury and major injury. Results: The age from $20-<30$ and from $10-<20$ years sustained auto tricycle injuries more than other age groups (34.7\% and $28 \%$; respectively). Males were exposed to accidents than females (77.3\% vs $22.7 \%$ ) and rural residents were more than urban residents (64\% vs 36\%). Passengers constituted $44 \%$ of victims and pedestrians constituted $22.7 \%$. Extremities (48.0\%) followed by head and neck injuries (40.3\%) were the most affected areas in the studied cases. Most cases had minor trauma; mild and moderate scores $(26.7 \%, 42.6 \%$ : respectively). Death and infirmity were significantly associated with major than minor injuries' cases ( $\mathrm{p}$ value $<\mathbf{0 . 0 0 1}$ ). Conclusion: Minor to moderate injuries were predominated in auto tricycle related accidents and the higher severity was associated with young victims and those had head and neck injuries and who needed prolonged duration of hospital stay, surgical treatment and ICU admission. Recommendations: Addition of seat belt to the design of auto tricycle for both the passenger and the driver and installations of doors for auto tricycle vehicles was recommended. Also, strict regulations about auto tricycle driving license and following the speed limit by the drivers are essential to decrease the risk for accidents.
\end{abstract}

Keywords:

Auto tricycles accidents; Pattern of injuries; Injury severity; Pedestrians; Drivers; Vehicle occupants 


\section{INTRODUCTION}

Injuries and death due to road traffic accidents (RTA) are a major but neglected emerging public health problem in developing countries (Bandara et al., 2019). This is particularly true in Egypt because of several factors such as poor infrastructure and quality of the majority of roads, the lack of regular road maintenance, and over-crowded traffic flows with trucks, pedestrians, motorcycles, buses, and motor vehicles all sharing the same road (Fouda et al., 2017).

Auto tricycle (Three-wheeled motorcycle) known as "Tok-Tok" in Egypt is a light weight, flexible and open vehicle designed to carry three adult passengers and a driver. Threewheeled motorcycle "Tok-Tok" is one of the widely used means of transportation in Egypt nowadays as they can easily reach the inaccessible city parts through narrow and poorly paved roads (Bolbol and Zalat, 2018). Furthermore, the high level of unemployment also made a lot of people to be Tok- Tok drivers because they are easy to drive and consume less fuel (Salako et al., 2013). Majority of them are young, without proper training, having no driving license and do not follow safety measures (Omoke et al., 2019).

The risk of severe injury to the auto tricycle occupants is increased by being an open vehicle without safety device such as seat belt and airbag (Chawla et al., 2003). The pedestrians hit by auto tricycle are also at risk of injury of varying degrees of severity depending on the orientation of the pedestrian on impact (Chawla et al., 2003).
Trauma scoring systems have been developed to evaluate the trauma severity and the prognosis after traumatic injury. The Injury Severity Score (ISS) is the most widely used anatomical scoring system for assessing the combined effect of multiple injuries and its value correlates with the risk of mortality (Ebrahimi et al., 2015).

Overall, there are a few researches conducted in Egypt that clarifies auto tricycle accidents pattern and outcome. Therefore, this study was conducted to assess pattern, injury severity level and factors associated with severity among auto tricycle accident victims who attended Menoufia University Hospital over one year.

\section{SUBJECTS AND METHODS:}

\section{Subjects:}

This was one year hospital based prospective study conducted on 225 victims who sustained auto tricycle vehicles' accidents and were admitted to Menoufia University Hospital during the period from the first of January to the end of December 2018. Subjects who died before reaching the hospital and subjects injured from auto tricycle (tricycle) which designed for transportation of goods were excluded from the current study.

\section{Methods:}

Data about victims were collected including demographic profile (age, sex and residence); accident data (nature of the incident, type of injury and type of victim); clinical data (region of the body affected, type of lesion, severity of injury, treatment and outcome). 
In addition, data about auto tricycle drivers was included as age, acquisition of license, driving experience and working hours/ day. Drug screening for drivers was performed using Qualitative immunoassay test for detection of tramadol and cannabinoids according to the method described by McBay, 1987.

Injury Severity Score (ISS) was used to determine the level of injury severity in the present study. ISS is an anatomical scoring system that provides an overall score for patients with multiple injuries consists of the squared and summed Abbreviated Injury Scale (AIS) scores of the three most severely injured body regions. The ISS score takes values from 0 to 75 and correlates linearly with mortality, morbidity, hospital stay and other measures of severity. It was categorized and validated the ISS as follows; $<9=$ Mild, $9-15=$ Moderate, 16- $24=$ Severe and $\geq 25=$ Profound (Bolorunduro et al., 2011). Major trauma is considered when ISS > 15 score (Javali et al., 2019). Accordingly, our study showed that injuries could be classified into major and minor trauma by an ISS cut-off value of 15 and the studied cases were categorized into two subgroups as with minor injury (ISS $\leq 15$ ) and with major injury (ISS > 15).

An informed written consent was obtained from all cases or legal guardians after clarification of the study aim. Collected data was kept strictly confidential and for the sole purpose of the study. Also, The Ethical Committee at Menoufia Faculty of Medicine has approved this study before its beginning.

\section{Statistical analysis:}

Data were analyzed using SPSS version 22.0 for Windows (California, USA). Qualitative were expressed as frequency and percentage and compared using Qui square $\left(\chi^{2}\right)$ and $\mathrm{Z}$ tests (test for proportions). Quantitative data were expressed as median and interquartile range (IQR) and compared using Mann-Whitney test (U). Level of probability ( $p$-value) less than 0.05 is used as the criterion of significance.

\section{RESULTS}

Table 1 showed that, the age from $20-<30$ and from $10-<20$ years sustained auto tricycle injuries more than other age groups $(34.7 \%$ and 28\%; respectively). Males were exposed to accidents than females $(77.3 \%$ vs $22.7 \%)$ and rural residents were more than urban residents $(64 \%$ vs $36 \%$ ).

The most common type of collision developed between auto tricycle with fixed objects and with vehicles $(32.4 \%, 26.2 \%$; respectively). More than half of accident occurred in the afternoon time $57.3 \%$. Passengers constituted $44 \%$ of victims and pedestrians constituted $22.7 \%$. Referred cases were $53.3 \%$ and $40.9 \%$ of cases arrived at hospital one to less two hours from the accident (Table 2).

Extremities (48.0\%) followed by head and neck injuries (40.3\%) were the most affected areas in the studied cases. Abrasions and contusion $(93.8 \%)$ followed by lacerations and contused wounds $(47.1 \%)$ were the most common lesions while abdominal organ injury was the least type (9.3\%). Regarding ISS, most cases had minor trauma; mild and moderate scores (26.7\%, 42.6\%: respectively). More than half of the cases $(54.7 \%)$ didn't need surgical interference and $24.4 \%$ of cases were admitted to ICU (Table $3)$. About $68 \%$ of cases improved while $16 \%$ developed infirmity and $16 \%$ died (Fig 1). Half of dead cases were died with the first 24 hours after 
admission. Infirmity included splenectomy, skull bone defect, nerve palsy, limb amputation and loss of eyes (Fig 2).

About $45.5 \%$ of auto tricycle drivers aged less than 18 years. Most of the drivers hadn't license, $(72.7 \%)$ with driving experience < 5years, $(75.8 \%)$ with average driving hours of more than 8 hours $(90.9 \%)$. About $27.3 \%$ of drivers had positive screening for tramadol and cannabis (Table 4).

Extremities followed by head and neck were mostly involved in pedestrians $(82.4 \%$ and $66.7 \%$ ), motor cyclists, pedal cyclists $(47.6 \%$ and $45.2 \%)$ and passengers $(32.3 \%$ and $23.2 \%)$ while chest $(72.7 \%)$ followed by head \& neck (45.5\%) were mostly involved in drivers (Table 5).

Abrasion \& contusion followed by limb fracture were the mostly common lesions in pedestrians $(100 \%$ and $74.5 \%$; respectively). In motor, pedal cyclist and passengers, abrasion $\&$ contusion followed by laceration \& contused wound were the mostly common lesions (90.5\%, 50.0\%, $92.9 \%$ and $32.3 \%$; respectively). In the other hand, abrasion \& contusion (90.9\%) followed by hemothorax \& pneumothorax $(57.6 \%)$ were the most common type in drivers (Table 6).

Table 7 showed that, collision between auto tricycle with vehicles and two wheeled motorcycle were significantly associated with major than minor injuries $\left(\chi^{2} 59.45\right.$ and $p$ value <0.001). Also, pedestrians, motor and pedal cyclists had significantly severe injuries than drivers $(p=0.01$

Victims aged $<10$ and from $10-$ $<20$ years were significantly associated with major than minor injuries $\left(\chi^{2}=24.37\right.$ and $p$ value $\left.<0.001\right)$. Head and neck and abdominal \& pelvis injuries were most common in major than minor injuries $(Z=3.51, p$ value $<0.001, Z=6.69$ and $p$ value $<0.001$; respectively). All types of lesions were significantly more common in major than minor injuries' subjects except abrasion \& contusions. Prolonged duration of hospital stay, surgical treatment, ICU admission and use of mechanical ventilation were significantly common in major than minor injuries' subjects ( $\mathrm{p}$ value $<0.001$ ). Death and infirmity were significantly associated with major than minor injuries' cases $\left(\chi^{2}=147.54\right.$ and $\mathrm{p}$ value $<0.001)$. In major trauma cases, the most common infirmity was splenectomy and limb amputation while nerve palsy, skull bone defect and loss of sight of eye were the most common .infirmity in minor cases $\left(\chi^{2}=36.00\right.$ and $\left.\mathrm{p}<0.001\right)$ as shown in (Table 8). 
Table 1: Demographic characteristics of auto tricycle accidents' victims regarding personal data.

\begin{tabular}{|l|l|l|}
\hline \multirow{2}{*}{ Variables } & \multicolumn{2}{|c|}{ The studied victims (n=225) } \\
\cline { 2 - 3 } & No & \% \\
\hline Age (years): & & \\
$<10$ & 15 & 6.7 \\
$10-<20$ & 63 & 28.0 \\
$20-<30$ & 78 & 34.7 \\
$30-<40$ & 43 & 19.1 \\
$40-<50$ & 17 & 7.5 \\
$\geq 50$ & 9 & 4.0 \\
\hline Sex: & & \\
Male & 174 & 77.3 \\
Female & 51 & 22.7 \\
\hline Residence: & & \\
Rural & 144 & 64.0 \\
Urban & 81 & 36.0 \\
\hline
\end{tabular}

Table 2: Frequency distribution of auto tricycle accidents' victims regarding accident data.

\begin{tabular}{|l|l|l|}
\hline \multirow{2}{*}{ Variables } & \multicolumn{2}{|l|}{ The studied victims (n=225) } \\
\cline { 2 - 3 } & No & \% \\
\hline Collision between auto tricycle with: & & \\
Vehicles & 59 & 26.2 \\
Two wheeled motorcycle & 18 & 8.0 \\
Pedal cyclist & 24 & 10.7 \\
Pedestrian & 51 & 22.7 \\
Fixed object & 73 & 32.4 \\
\hline Time of accident: & & \\
Morning & 51 & 22.7 \\
Afternoon & 129 & 57.3 \\
At night & 45 & 20.0 \\
\hline Type of victim: & & \\
Pedestrians & 51 & 22.7 \\
Motor \& pedal cyclists & 42 & 18.7 \\
Passengers & 99 & 44.0 \\
Drivers & 33 & 14.7 \\
\hline Referral: & & \\
Yes & 120 & 53.3 \\
No & 105 & 46.7 \\
\hline Time from accident to hospital & & \\
arrival (hour): & & \\
$<1$ & 76 & 33.8 \\
1- <2 & 92 & 40.9 \\
$\geq 2$ & 57 & 25.3 \\
\hline
\end{tabular}


Table 3: Frequency distribution of auto tricycle accidents' victims regarding clinical data and outcome.

\begin{tabular}{|l|l|l|}
\hline Variables & \multicolumn{2}{|l|}{ The studied victims (n=225) } \\
\cline { 2 - 3 } & No & \% \\
\hline Site of injury: & & \\
Head and neck & 91 & 40.3 \\
Chest & 57 & 25.3 \\
Abdomen and Pelvis & 33 & 14.7 \\
Extremities & 108 & 48.0 \\
\hline Type of lesions: & & \\
Abrasions \&/or Contusions & 211 & 93.8 \\
Lacerations \&/or contused wounds & 106 & 47.1 \\
Skull fracture \&/or Intracranial hemorrhage & 63 & 28.0 \\
Limb fracture & 88 & 39.1 \\
Limb nerve \&/or vascular trauma & 47 & 20.9 \\
Hemothorax\&/or pneumothorax & 35 & 15.6 \\
Abdominal organ Injury & 21 & 9.3 \\
\hline ISS: & & \\
Mild (<9) & 60 & 26.7 \\
Moderate (10-15) & 96 & 42.6 \\
Severe (16-24) & 27 & 12.0 \\
Profound ( $\geq 25)$ & 42 & 18.7 \\
\hline Severity: & & \\
Minor trauma (ISS $\leq 15)$ & 156 & 69.3 \\
Major trauma (ISS >15) & 69 & 30.7 \\
\hline Treatment: & & \\
Conservative & 123 & 54.7 \\
Surgical & 102 & 45.3 \\
\hline Hospital stay (days) & $5(3)$ & \\
Median (IQR) & $1-21$ & \\
range & 55 & 24.4 \\
\hline ICU admission: & 170 & 75.6 \\
Yes & 180 & 80.0 \\
No & & \\
\hline Mechanical ventilation: & \\
Yes & & \\
No & & \\
\hline
\end{tabular}


Table 4: Work related data and drug screening finding for studied auto tricycle drivers.

\begin{tabular}{|l|l|l|}
\hline \multirow{2}{*}{ Variables } & \multicolumn{2}{|l|}{ Drivers $(\mathbf{n}=\mathbf{3 3})$} \\
\cline { 2 - 3 } & No & \% \\
\hline Age (years): & & \\
$<18$ & 15 & 45.5 \\
$\geq 18$ & 18 & 54.5 \\
\hline Driver's license & & \\
Yes & 9 & 27.3 \\
No & 24 & 72.7 \\
\hline Driving experience & & \\
$<5$ years & 25 & 75.8 \\
$\geq 5$ years & 8 & 24.2 \\
\hline Daily driving hours & & \\
$<8$ & 3 & 9.1 \\
$\geq 8$ & 30 & 90.9 \\
\hline Drug screening & & \\
Tramadol & 3 & 9.1 \\
Cannabis & 4 & 12.1 \\
Mixed & 2 & 6.1 \\
Negative analysis & 24 & 72.7 \\
\hline
\end{tabular}

Table 5: Distribution of type of victims regarding site of injury.

\begin{tabular}{|c|c|c|c|c|c|c|c|c|}
\hline \multirow[t]{2}{*}{ Site of injury } & \multicolumn{2}{|c|}{$\begin{array}{c}\text { Pedestrians } \\
\quad(n=51)\end{array}$} & \multicolumn{2}{|c|}{$\begin{array}{c}\text { Motor \& } \\
\text { pedal } \\
\text { Cyclists } \\
(n=42) \\
\end{array}$} & \multicolumn{2}{|c|}{$\begin{array}{l}\text { Passengers } \\
(n=99)\end{array}$} & \multicolumn{2}{|c|}{$\begin{array}{c}\text { Drivers } \\
(n=33)\end{array}$} \\
\hline & No. & $\%$ & No. & $\%$ & No. & $\%$ & No. & $\%$ \\
\hline Head and Neck & 34 & 66.7 & 19 & 45.2 & 23 & 23.2 & 15 & 45.5 \\
\hline Chest & 8 & 15.7 & 10 & 23.8 & 15 & 15.2 & 24 & 72.7 \\
\hline Abdomen \&Pelvis & 5 & 9.8 & 5 & 11.9 & 21 & 21.2 & 2 & 6.1 \\
\hline Extremities & 42 & 82.4 & 20 & 47.6 & 32 & 32.3 & 14 & 42.4 \\
\hline
\end{tabular}

Table 6: Distribution of victims regarding type of lesions.

\begin{tabular}{|c|c|c|c|c|c|c|c|c|}
\hline \multirow[t]{2}{*}{ Type of lesions } & \multicolumn{2}{|c|}{$\begin{array}{c}\text { Pedestrians } \\
(\mathbf{n}=51)\end{array}$} & \multicolumn{2}{|c|}{$\begin{array}{l}\text { Motor \& } \\
\text { pedal } \\
\text { cyclists } \\
(n=42)\end{array}$} & \multicolumn{2}{|c|}{$\begin{array}{l}\text { Passengers } \\
(\mathbf{n}=99)\end{array}$} & \multicolumn{2}{|c|}{$\begin{array}{c}\text { Drivers } \\
(n=33)\end{array}$} \\
\hline & $\mathbf{N}$ & $\%$ & $\mathbf{N}$ & $\%$ & $\mathbf{N}$ & $\%$ & $\mathbf{N}$ & $\%$ \\
\hline Abrasions \&/or Contusions & 51 & 100 & 38 & 90.5 & 92 & 92.9 & 30 & 90.9 \\
\hline Lacerations \&/or contused wounds & 35 & 68.6 & 21 & 50.0 & 32 & 32.3 & 18 & 54.5 \\
\hline Skull fracture \&/or Intracranial hemorrhage & 24 & 47.1 & 14 & 33.3 & 15 & 15.2 & 10 & 30.3 \\
\hline Limb fracture & 38 & 74.5 & 17 & 40.5 & 21 & 21.2 & 12 & 36.4 \\
\hline Limb nerve \&/or vascular trauma & 23 & 45.1 & 4 & 9.5 & 9 & 9.1 & 11 & 33.3 \\
\hline Hemothorax\&/or pneumothorax & 5 & 9.8 & 6 & 14.3 & 5 & 5.1 & 19 & 57.6 \\
\hline Abdominal organ Injury & 3 & 5.9 & 1 & 2.4 & 12 & 12.1 & 3 & 9.1 \\
\hline
\end{tabular}


Table 7: Qui squre statistical analysis for the relationship between accident data of auto tricycle accidents' victims and injury severity.

\begin{tabular}{|c|c|c|c|c|}
\hline \multirow[t]{2}{*}{ Accident data } & \multicolumn{2}{|c|}{ Injury severity } & \multirow[t]{2}{*}{$\chi^{2}$} & \multirow[t]{2}{*}{ p-value } \\
\hline & $\begin{array}{c}\text { Minortrauma } \\
\text { ISS } \leq 15 \\
(\mathbf{n}=156) \\
\text { No }(\%)\end{array}$ & $\begin{array}{c}\text { Mijortrauma } \\
\text { ISS >15 } \\
(n=69) \\
\text { No }(\%)\end{array}$ & & \\
\hline $\begin{array}{l}\text { Collision between auto } \\
\text { tricycle with: } \\
\text { Vehicles } \\
\text { Two wheeled motorcycle } \\
\text { Pedal cyclist } \\
\text { Pedestrian } \\
\text { Fixed object }\end{array}$ & $\begin{array}{l}38(24.4) \\
0 \\
24(15.4) \\
33(21.2) \\
61(21.2) \\
\end{array}$ & $\begin{array}{c}21(30.4) \\
18(26.1) \\
0 \\
18(26.1) \\
12(17.4) \\
\end{array}$ & 59.45 & $<0.001 *$ \\
\hline $\begin{array}{l}\text { Type of victim: } \\
\text { Pedestrians } \\
\text { Motor \& pedal cyclists } \\
\text { Passengers } \\
\text { Drivers }\end{array}$ & $\begin{array}{l}33(21.2) \\
24(15.4) \\
69(44.2) \\
30(19.2)\end{array}$ & $\begin{array}{c}18(26.1) \\
18(26.1) \\
30(43.5) \\
3(4.3) \\
\end{array}$ & 10.68 & $0.014 *$ \\
\hline $\begin{array}{l}\text { Referral: } \\
\text { Yes } \\
\text { No } \\
\end{array}$ & $\begin{array}{l}84(53.8) \\
72(46.2)\end{array}$ & $\begin{array}{l}36(52.2) \\
33(47.8)\end{array}$ & 0.05 & 0.817 \\
\hline
\end{tabular}

* Significant $(\mathrm{p}-$ value $<0.05)$ 
Table 8: Statistical analysis for the relationship between clinical data of auto tricycle accidents' victims and injury severity.

\begin{tabular}{|c|c|c|c|c|}
\hline \multirow[t]{2}{*}{ Clinical data } & \multicolumn{2}{|c|}{ Injury severity } & \multirow{2}{*}{$\begin{array}{c}\text { Test of } \\
\text { significance }\end{array}$} & \multirow[t]{2}{*}{ p- value } \\
\hline & $\begin{array}{c}\text { Minortrauma } \\
\text { ISS } \leq 15 \\
(\mathbf{n}=156) \\
\text { No }(\%) \\
\end{array}$ & $\begin{array}{c}\text { Mijortrauma } \\
\text { ISS >15 } \\
(\mathbf{n}=69) \\
\text { No }(\%)\end{array}$ & & \\
\hline $\begin{array}{l}\text { Age (years): } \\
<10 \\
10-<20 \\
20-<30 \\
30-<40 \\
40-<50 \\
\geq 50\end{array}$ & $\begin{array}{c}3(1.9) \\
42(26.9) \\
57(36.5) \\
42(26.9) \\
6(3.8) \\
6(1.9)\end{array}$ & $\begin{array}{c}12(17.4) \\
21(30.4) \\
21(30.4) \\
9(13.0) \\
3(4.3) \\
3(4.3)\end{array}$ & $\chi^{2}=24.37$ & $<0.001 *$ \\
\hline $\begin{array}{l}\text { Site of injury: } \\
\text { Head and neck } \\
\text { Chest } \\
\text { Abdomen and pelvis } \\
\text { Extremities }\end{array}$ & $\begin{aligned} & 48(30.8) \\
& 45(28.8) \\
& 6(3.8) \\
& 69(44.2) \\
&\end{aligned}$ & $\begin{array}{l}39(56.5) \\
12(17.4) \\
27(39.1) \\
39(56.5)\end{array}$ & $\begin{array}{l}Z=3.51 \\
Z=1.66 \\
Z=6.69 \\
Z=1.83\end{array}$ & $\begin{array}{c}<\mathbf{0 . 0 0 1} * \\
0.098 \\
<\mathbf{0 . 0 0 1} * \\
0.068\end{array}$ \\
\hline $\begin{array}{l}\text { Type of lesions: } \\
\text { Abrasions \&/or Contusions } \\
\text { Lacerations \&/or contused wounds } \\
\text { Skull fracture \&/or Intracranial } \\
\text { hemorrhage } \\
\text { Limb fracture } \\
\text { Limb nerve \&/or vascular trauma } \\
\text { Hemothorax\&/or pneumothorax } \\
\text { Abdominal organ Injury }\end{array}$ & $\begin{array}{c}156(100.0) \\
50(32.1) \\
12(7.7) \\
\\
49(31.4) \\
12(7.7) \\
6(3.8) \\
7(4.5) \\
\end{array}$ & $\begin{array}{l}26(37.7) \\
56(81.2) \\
51(73.9) \\
\\
39(56.5) \\
35(50.7) \\
29(42.0) \\
14(20.3) \\
\end{array}$ & $\begin{aligned} & Z=10.78 \\
& Z=6.66 \\
& Z=10.04 \\
& \\
& Z=3.41 \\
& Z=7.14 \\
& Z=7.09 \\
& Z=3.51 \\
&\end{aligned}$ & $\begin{array}{l}<0.001 * \\
<0.001 * \\
<0.001 * \\
\\
\\
0.001 * \\
<0.001 * \\
<0.001 * \\
<0.001 *\end{array}$ \\
\hline $\begin{array}{l}\text { Hospital stay (days) } \\
\text { Median (IQR) }\end{array}$ & $3(2)$ & $12(3)$ & $\mathrm{U}=6.38$ & $<0.001 *$ \\
\hline $\begin{array}{l}\text { Treatment: } \\
\text { Conservative } \\
\text { Surgical }\end{array}$ & $\begin{array}{r}102(65.4) \\
54(34.6) \\
\end{array}$ & $\begin{array}{l}21(30.4) \\
48(69.6)\end{array}$ & $\chi^{2}=23.58$ & $<0.001 *$ \\
\hline $\begin{array}{l}\text { ICU admission: } \\
\text { Yes } \\
\text { No }\end{array}$ & $\begin{array}{c}9(5.8) \\
147(94.2) \\
\end{array}$ & $\begin{array}{l}36(52.2) \\
33(47.8) \\
\end{array}$ & $\chi^{2}=64.39$ & $<0.001 *$ \\
\hline $\begin{array}{l}\text { Mechanical ventilation: } \\
\text { Yes } \\
\text { No }\end{array}$ & $\begin{array}{c}3(1.9) \\
153(98.1)\end{array}$ & $\begin{array}{l}27(39.1) \\
42(60.9)\end{array}$ & $\chi^{2}=57.31$ & $<0.001 *$ \\
\hline $\begin{array}{l}\text { Outcome: } \\
\text { Improved } \\
\text { Improved with infirmity } \\
\text { Died }\end{array}$ & $\begin{array}{c}144(92.3) \\
12(7.7) \\
0 \\
\end{array}$ & $\begin{array}{c}9(13.0) \\
24(34.8) \\
36(52.2) \\
\end{array}$ & $\chi^{2}=147.54$ & $<0.001 *$ \\
\hline $\begin{array}{l}\text { Type of infirmity: } \\
\text { Splenectomy } \\
\text { Skull bone defect } \\
\text { Nerve palsy } \\
\text { Amputation } \\
\text { Loss of sight of eye }\end{array}$ & $\begin{array}{c}\quad(\mathrm{n}=12) \\
0 \\
3(25.0) \\
6(50.0) \\
0 \quad 3(25.0) \\
\end{array}$ & $\begin{array}{l}\quad(\mathrm{n}=24) \\
18(75.0) \\
0 \\
0 \\
6(25.0) \\
0\end{array}$ & $\chi^{2}=36.00$ & $<0.001 *$ \\
\hline
\end{tabular}

IQR: interquartile range

U: Mann-Whitney test

* Significant $(\mathrm{p}-$ value $<0.05)$ 


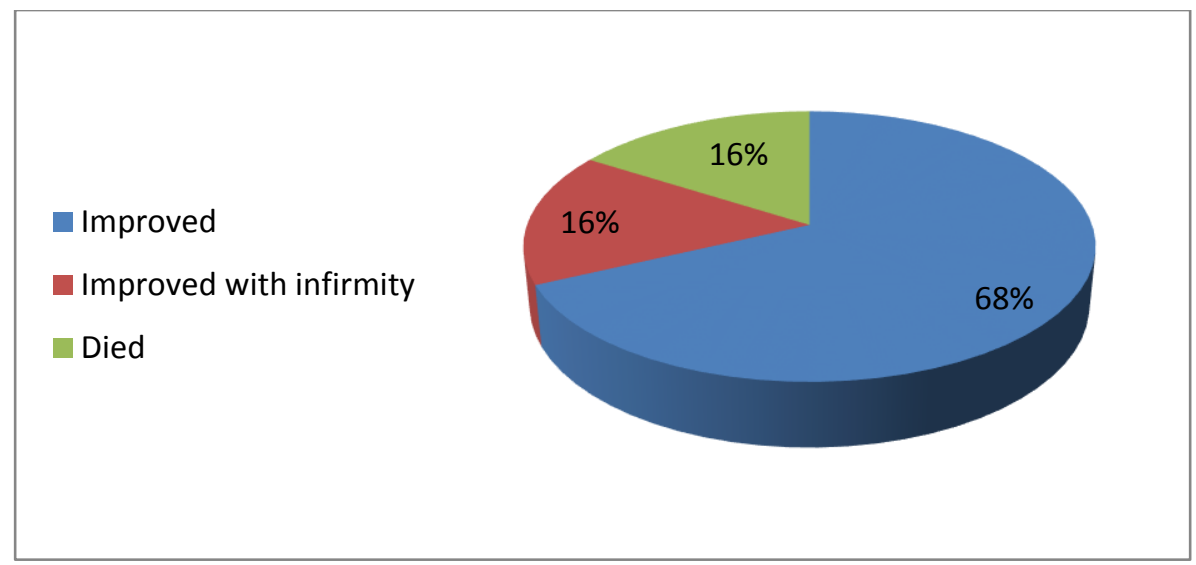

Fig (1): Percent distribution of the studied cases regarding their outcome



Fig (2): Percent distribution of types of infirmity among the studied cases.

\section{DISCUSSION}

Auto tricycle is a common means of public transport in Egypt due to their economic and physical feasibility compared to other means of transportation. Also, the high level of unemployment made a lot of people to work as drivers for motorcycle taxis “Tok-Tok" (Salako et al., 2013).

A total of 2030 road traffic accidents victims were admitted to Menoufia University hospital in a year 2018. Among these cases, auto tricycle accidents accounted 225 cases $(11.1 \%)$ (results are not tabulated). In another study conducted by Kandeel and Elagamy (2018) on road traffic accident cases arrived at Menoufia University hospital from first of July 2016 to end of June 2017, three-wheel motorcycle cases constituted $26.9 \%$ of all cases. This disagreement could be due to exclusion of subjects died before reaching the hospital from the present study. Also, the previous study included victims of three-wheel motorcycle which designed for transportation of goods that were excluded in our study. 
Middle aged victims (from 20-30 years) were the most common cases in this study. This result was consistent with previous studies in Egypt (Bolbol and Zalat, 2018) and other countries (Mansuri et al., 2015; Bandara et al., 2019) as this age was more involved in work activities. The involvement of older age groups in traffic related injuries were noted in high-income countries than in low-and middleincome countries. This difference was most likely related to longevity in these countries (World Health Organization, 2013).

In the present study, $77.3 \%$ of victims were males as being more involved in outdoor works and commonly exposed to accidents. Most of them were the only source of income for their family leading to huge economic loss (Kumar et al., 2019). Also, most of the cases came from rural areas as Menoufia is a rural governorate. Moreover, the streets in rural areas are mostly narrow with low quality, poor illumination and lack of traffic signs (de Oliveira and de Sousa, 2011). Also, people from rural areas need to travel to cities for different purposes as working, learning and buying their needs (Singh et al., 2016).

Collisions between auto tricycle with fixed objects, such as trees, walls, and roadside barriers were mostly reported by the studied victims. This might be due to a considerable number of drivers aged less than 18 years with poor driving experience. On the other hand, the study of Schmuker et al. (2011) reported that collision with single-vehicle was the commonest type.

This study highlighted that most of accidents took place in the afternoon. This can be attributed to hurry to get back to home after completion of work and due to the long-time driving. This was in line with the result of Singh et al., (2016) in India. However, other study of Shrestha et al., (2017) in Nepal as most accidents developed in the foggy morning time which reduces the vision on the road.

Passengers constituted $44 \%$ of the victims and the pedestrians constituted $22.7 \%$ in the present study. This reflected the higher danger exposure of autotricycle passengers as it is an open vehicle without doors or seat belt. Also, one vehicle transports more than one passenger so, one crash injured many passengers. This result was coincided with Shalaby et al. (2010) who stated that transportation vehicles with several passengers are frequently involved in crashes in developing countries. While, Ranjan et al., (2017) found that pedestrians were the majority of road traffic accidents' victims in India but the study included accidents' victims form all types of vehicles.

More than half of the studied cases were referred to the University hospitals for the availability of senior treating staff, intensive care unit and computerized tomography (CT) scan which are not available in the central hospitals. About $40.9 \%$ of cases arrived at hospital within one to less than two hours from the accident. The hospital stay for the studied cases ranged from 1 to 21 days with an average of 5 days. This was in line with the results made by El-Fiki and El Falaky, (2016).

Extremities (48.0\%) followed by head and neck injuries (40.3\%) were the most affected areas in the studied cases. Also, Omoke et al. (2019) found that the lower extremity $(50 \%)$, head $(38.6 \%)$ and upper extremity $(30.4 \%)$ were the three top anatomical regions involved. Moreover, abrasions and contusions were the most common lesions in the present study followed by lacerations and contused wounds while abdominal organ injury was the 
least type. This reflected multiplicity of injuries among the studied victims.

The study revealed that $68 \%$ of cases improved and more than half of the cases $(54.7 \%)$ didn't need surgical interference as $69.3 \%$ of the cases had mild and moderate injuries having an ISS $\leq 15$. This pattern was nearly similar to the findings of Ibeanusi and Diamond (2018) in Nigeria. Half of the dead cases died within the first 24 hours of the accidents. Also, this result was previously recorded by Kual et al., (2005).

Recovery with infirmity was the outcome in $16 \%$ of the cases. Splenetomy was performed in half of them. On the other hand, El Bakash et al. (2016) recorded complicated recovery in $8 \%$ pedestrians and in $16 \%$ of vehicle occupants in the form of shoulder disfigurement, limping, amputation and trephine operation but they included all types of road traffic injuries in great Cairo.

About one quarter of the cases (24.4\%) was admitted to ICU. Road traffic crushes have been reported to be the commonest cause of ICU trauma admissions in most studies (Chalya et al., 2010; Amanor-Boadu et al., 2003) and motorcycle injuries accounted for more than fifty percent of road traffic injuries that might be attributed to negligence of the driver, poor maintenance of vehicles, driving under the influence of alcohol or drugs and disregard of traffic laws. (Chalya et al., 2011)

The present study demonstrated that most of drivers did not have license and with driving experience < 5years with more than 8 daily driving hours $\quad(72.7 \%, \quad 75.8 \%, \quad 90.9 \%$; respectively) and nearly half of them $(45.5 \%)$ were less than 18 years old. All of these were considered risk factors for accident development especially when associated with overcrowded poor road facilities. In the contrast, the results of Shrestha et al., (2017) revealed that increased year of experience of driver was associated with RTAs due to carelessness behavior of the driver. Moreover, the results showed that $27.3 \%$ of drivers had positive screening for tramadol and cannabis at the time of accidents. Similarly, drug intake was linked to accidents in $21.1 \%$ of motorcycle riders in the Egyptian study of Shaker et al., (2014).

Regarding site of lesions affecting victims, limb injuries were more in pedestrians and motorcyclist as the collision with the vehicle affecting mainly lower limbs (primary impact injuries), then they are thrown to the ground (secondary injuries) where any part of the body can be injured (Nzegwu et al., 2011). Similarly, El Bakash et al. (2016) reported that lower limbs were the most frequent site affected in pedestrians. Head and neck was the second site affected this might be attributed to greater distance of fall in them (Seethalakshmi et al., 2015; Rajesh et al., 2012).

Auto tricycle occupants including passengers and drivers were differ regarding their sites of injury where the commonest site among passengers were extremities followed by head and neck while chest followed by head and neck were the commonest among drivers. Passengers were mostly injured by being thrown out from the vehicle or impacted the front metal bar inside the vehicle while the drivers sustained injuries from impacts on to front of the chest against the handlebar and structures such as windscreen. Therefore, hemothorax and pneumothorax were higher in drivers (Chen and Gabler 2014).

Collision between auto tricycle with vehicles and two wheeled 
motorcycle were significantly associated with major injuries. Crashes with larger vehicles resulted in high ISS due to excessive speed, also correlated to the high level of energy (Javouhey et al., 2006). This result agreed with the study of Lam et al., (2019). Motorcycle riders suffered severe injuries especially severe head trauma as most of them did not wear helmets (Sisimwo et al., 2014). Passengers had significantly severe injuries than drivers who can momentary predict the accident. Due to the instability of the vehicle, when collision occurs the victim is ejected from the tricycle which is an open vehicle without seat belt, he often strikes the ground or another vehicle (Omoke et al., 2019). Moreover, Daskal et al., (2018) studied injury patterns according to seat position in occupants of private cars. They recorded that drivers are less likely to be injured severely than passengers sitting in the rear.

Regarding factors associated with major injuries (ISS $>15$ ), the results of this study revealed that the younger victims $(<20$ years) were more prone to serious injuries. This finding might be due to the predominance of motorcyclists riders in severe cases who were mostly young aged and rode motorcycle primarily for recreational or touring purposes (McCartt et a., 2011). For the same reason, head and neck injuries predominated in major trauma cases. Also, the head and neck injuries were the most common traumatized anatomic areas leading to mortality in the study of Modaghegh et al. (2013).

Injury severity was associated with prolonged duration of hospital stay, surgical treatment and ICU admission in the studied cases. Prolonged length of hospital stay could lead to waste of resources as well as functional decline
(Moore et al., 2018). This result coincided with the study of Moore et al. (2014) who revealed a significant association between trauma score and injury severity with length of hospital stay in Canada. Moreover, a study Chabok et al. (2017) reported that injury severity score (ISS) was the best predictor for length of hospital stay. Moreover, Mortality of the studied cases in this study was strongly associated with higher Injury Severity Score (ISS). This finding coincided with Alberdi et al. (2014) who reported that $55 \%$ of dead trauma cases occurred within the first 24 hour of trauma, with a higher Injury Severity Score (ISS)

\section{CONCLUSION}

Considering the results obtained from the present study it can be concluded that, auto tricycle-related accidents were more common among young and middle aged males at rural areas. Most of auto tricycles' drivers hadn't drive license. Passengers followed by pedestrians were the commonly affected victims. The most common type was abrasion and contusion, specifically on the extremities followed by head and neck but chest was more affected among drivers. Minor injuries were predominated in auto tricycle accidents and the higher severity was associated with young victims and those had head and neck injuries and who needed prolonged duration of hospital stay, surgical treatment and ICU admission.

\section{RECOMMENDATIONS}

In order to reduce the incidence of auto tricycle accidents, several measures are recommended which include the addition of seat belt to the design of auto tricycle for both the passenger and the driver and installations of doors for auto tricycle 
vehicles was recommended. Also, strict regulations about auto tricycle driving license and following the speed limit by the drivers are essential to decrease the risk for accidents. In addition, road safety maintenance and separation of road users are recommended.

\section{REFERENCES}

Alberdi, F.; García, I.; Atutxa, L. and Zabarte, M. (2014): Trauma and Neurointensive Care Work Group SEMICYUC.

Epidemiología of severe trauma. Medcina Intensiva, 38:580-88.

Amanor-Boadu, S.D.; Sanusi, A.A.; Oyeleke, S.O. and Soyannwo O. A (2003): Intensive Care for Trauma Victims in a Developing Country: Priorities and Challenges for Improvement. Afr J Trauma, 1: 51-3.

Bandara, K.V.; Vadysinghe, A.N. and Edussuriya, D.H. (2019): Medico Legal Aspects of Injuries Sustained by Occupants of Three Wheelers in Road Traffic Crashes. Sri Lanka Journal of Forensic Medicine, Science \& Law, 10 (1):25-33.

Bolbol, S.A. and Zalat, M.M. (2018): Motorcycle Riders' Risky Behaviors and Safety Measures: A Hospital-Based Study, Egyptian Journal of Occupational Medicine, 42 (3): 453-68.

Bolorunduro, O.B.; Villegas, C.; Oyetunji, T. A.; Haut, E.; Stevens, K.A.; Chang D. C., Cornwell E.E., Efron D.T. and Haider A.H. (2011): Validating the Injury Severity Score (ISS) in different populations: ISS predicts mortality better among Hispanics and females. J Surg Res, 166(1):40-4.

ChabokS, Y. F.; Taklimie, R.; Malekpouri, R. and Razzaghi, A. (2017): Predicting mortality, hospital length of stay and need for surgery in pediatric trauma patients Chinese Journal of Traumatology, 20(6):339-42.

Chalya, P.L.; Gilyoma, J.M.; Dass, R.M.; Mchembe,M.D.; Matasha, M.; Mabula, J.B.; et al. (2011): Trauma admissions to the Intensive care unit at a reference hospital in Northwestern Tanzania. Scand J Trauma Resusc Emerg Med, $19 . \quad 61$. https://doi.org/10.1186/17577241-19-61

Chalya, P.L.; Mabula, J.B.; Ngayomela, I.H.; Kanumba, E.S.; Chandika, A.B., Giiti, G.; et al. (2010): Motorcycle injuries as an emerging public health problem in Mwanza City, northwestern Tanzania. Tanzania Journal of Health Research, 12: 214-21.

Chawla, A.; Mukherjee, S.; Mohan, D.; Singh, J. and Rizvi, N. (2003): Crash Simulation of Three Wheeled Scooter Taxi (TST). New Delhi: Indian Institute of Technology, 1-14.

Chen, R. and Gabler, H. (2014): Risk of thoracic injury from direct steering wheel impact in frontal crashes, Journal of Trauma and Acute Care Surgery, 76(6):1441-6.

Daskal, Y.; Alfici, R.; Givon, A.; Peleg, K.; Olsha, O. and Kessel, B. (2018): Evaluation of differences in injury patterns according to seat position in trauma victims survived traffic accidents, Chinese Journal of Traumatology, 21: 273-276.

de Oliveira, N. L. B. \& de Sousa, R. M. C. (2011): Traffic accidents with motorcycles and their relationship to mortality. Revista Latino-Americana Enfermagem, 19 (2) 403-410

Ebrahimi, M.; Pirazghandi, H. and Reihani RH. (2015): How is the 
injury severity scored? a brief review of scoring systems. Rev Clin Med, 2(3):125-8.

El Bakash, O. H; Kabbash, A.M.; El Gohary, M. S. and Amal SAF Hafez, A. S. (2016): Evaluation of The Patterns of Injuries in Road Traffic Accidents in Great Cairo, Egypt, Egypt J. Forensic Sci. Appli. Toxicol, 16(2): 79-95.

El-Fiki, A. and El Falaky, O. (2016): Evaluation of neurotrauma in motorcycle related accidents at a tertiary hospital in Egypt. Egypt $\mathbf{J}$ Neurol Psychiatry Neurosurg [Internet], 53(4):244 -47.

Fouda, E.; Youssef, M.; Emile, S.H.; Elfeki, H.; Thabet, W.; Abdallah, E.; et al. (2017): Pattern of major injuries after motorcycle accidents in Egypt: The Mansoura Emergency Hospital experience, Trauma, 19(1): 39-45.

Ibeanusi, S.E.; Diamond, T.E.(2018): Traffic related injuries from a trauma registry: Pattern and outcome. Niger J Orthop Trauma, 17:22-8.

Javali, R.H.; Krishnamoorthy; Patil, A.; Srinivasarangan, M.; Suraj; Sriharsha (2019): Comparison of Injury Severity Score, New Injury Severity Score, Revised Trauma Score and Trauma and Injury Severity Score for Mortality Prediction in Elderly Trauma Patients. Indian J of Crit Care Med , 23(2):73-7.

Javouhey, E.; Guérin, A.C. and Chiron, M. (2006): Incidence and risk factors of severe traumatic brain injury resulting from road accidents: a population-based study. Accid Anal Prev, 38(2):225-33.

Kandeel, F. and Elagamy, S. (2018). A prospective study on road traffic accident cases arrived at menoufia university hospital over one year
Egypt j. Forensic sci. Appli. Toxicol, 18 (2): 99-118.

Kual, A.; Sinha, U.S.; Pathak, Y.K.; Singh, A.; Kapoor, A.K.; Sharma, S.; et al. (2005): Fatal Road Traffic Accidents, Study of Distribution, Nature and Type of Injury, JIAFM, 27 (2):71-76.

Kumar, K. P.; Kumar, M.U.; Sekhar, V.C.; Krishna, R. (2019): Analysis of Pedestrian Deaths in Road Traffic Accidents -An Autopsy Based Study in Visakhapatnam, East African Scholars J Med Sci, 2 (2): 74-79.

Lam, C.; Pai, C-W.; Chuang, C-C.; Yen, Y-C.; Wu, C-C.; Yu, S-H.; et al. (2019): Rider factors associated with severe injury after a light motorcycle crash: A multicentre study in an emerging economy setting. PLoS ONE 14(6): e0219132.

Mansuri, F.A.; Al-Zalabani, A.H.; Zalat, M.M. and Qabshawi, R. I. (2015): Road safety and road traffic accidents in Saudi Arabia. A systematic review of existing evidence. Sadi Med J, 36 (4):41824

McBay, A. (1987): Drug analysis technology-pitfalls and problems of drug testing. Clin. Chem, 33(11):33-40.

McCartt, A.T.; Blanar, L.; Teoh, E.R. and Strouse, L.M. (2011): Overview of motorcycling in the United States: a national telephone survey. J Safety Res, 42:177-84.

Modaghegh, M.H.; Saremi, E.; Mohamadian, M. and Jafarzadeh, R. (2013): Characteristics of trauma in North East Iran and the prevention strategies. Arch Iran Med, 16(10):576-9.

Moore, L.; Stelfox, H.T.; Evans, D.; Hameed, S.M. and Yanchar, N.L. (2018): Hospital and intensive care unit length of stay for injury admissions: a pan- 
Canadian cohort study Ann Surg, 267:177-82.

Moore, L.; Stelfox, H.T.; Turgeon, A.F.; Nathens, A.; Bourgeois, G.; Lapointe, J.; et al (2014): Hospital length of stay after admission for traumatic injury in Canada: a multicenter cohort study Ann Surg, 179-187,

Nzegwu, M.A.; Akhiwu, W.; Nzegwu, C.O; Ibeziakor, N.; Banjo A.A., Aligbe, J.U.; et al. (2011): Analysis of Patterns of Morbidity and Mortality amongst Pedestrians involved in Road Traffic Accident in Benin City Nigeria between August 2003 July 2004, Advances in bioresearch, 2 (1): $144-7$.

Omoke, N.I.; Lasebikan. O.A.; Onyemaechi, N.O. and Ajali, N. (2019): Auto tricycle injuries and the vulnerability of occupants and pedestrians in a developing Country: A multi-center study. Niger J Clin Pract , 22:971-6.

Rajesh, D.R.; Balbir, K.; Abhishek, S.; Venkteshan, M., Aggarwal, O.P. and Harpreet, S. (2012): Pattern of Injuries due to Fatal Road Traffic Accidents in Rural Haryana: An Epidemiological Survey, Journal of Indian Academy of Forensic Medicine, 34(3):229-32.

Ranjan, R.; kumar, D. and Lal, S. (2017): Pattern and Distribution of Injuries in Fatal Road Traffic Accident Cases, Journal of Dental and Medical Sciences, 16 (3):71-4.

Salako, A.; Abiodun, O. and Sholeye, O. (2013): Risk behaviors for road traffic accidents and severe crash injuries among commercial motorcyclists in Sagamu, South West, Nigeria. Online J Med Sci Res, 2: 19-23.

Schmuker, U.; Dandona. R.; Kumar, G.A. and Dandona, L. (2011): Crashes involving motorised rickshaws in urban India: Characteristics and injury pattern. Injury, 42:104-11.

Seethalakshmi, M.; Sudalaimuthu, R.; Mahendran, J. and Nagendrakumar, A. (2015): Study of Injury Pattern in Human Beings in Road Traffic Accidents Involving Two Wheelers, Journal of Evolution of Medical and Dental Sciences, 4 (77): 13436-58.

Shaker, R.H.; Eldesouky, R.S.; Hasan, O.M. and Bayomy, $H$. (2014): Motorcycle Crashes: Attitudes of the Motorcyclists Regarding Riders' Experience and Safety Measures, J Community Health, 39:1222-30.

Shalaby, S.A.; Akeed, Y.A.; Fawzi, M.M.; Nabil, D.M. (2010): Prospective study of some medicolegal aspects of road traffic accidents in great Cairo 2007. International journal of academic research, 2(2):127-37.

Shrestha, V.L.; Bhatta, D.N.; Shrestha, K.M.; Bahadur. K and Paudel, S. (2017): Factors and Pattern of Injuries Associated with Road Traffic Accidents in Hilly District of Nepal. Journal of Biosciences and Medicines, 5: 88100.

Singh, D.; Singh, S.P.; Kumaran, M. and Goel, S. (2016): Epidemiology of Road Traffic Accident Deaths in Children in Chandigarh Zone of North West India. Egyptian Journal of Forensic Sciences, 6 (3): 255-60.

Sisimwo, P. K.; Mwaniki, P. K. and Bii, C. (2014): Crash characteristics and injury patterns among commercial motorcycle users attending Kitale level IV district hospital, Kenya, Pan African Medical Journal, 19:296.

World Health Organization. (2013). Global status report on road safety 2013: Supportin 


\title{
الملخص العربي
}

\section{نمط و خطورة إصابات المركبات ثلاثية العجلات (التوك توك): دراسة مستقبلية لمدة عام واحد}

\author{
مفرح محمد حجازي و شيرين رجب سليمة \\ قسم الطب الثرعي والسموم الاكلينيكية ـ كلية الطب - جامعة المنوفية
}

المقدمة: تعتبر المركبات ثلاثية العجلات "التوك نوك" هي واحدة من وسائل النقل المستخدمة على نطاق واسع في مصر في الوقت الحاضر،كما أن هناك زيادة في حدوث الإصابات الناتجة عن الحوادث ذات الصلة باستخدامها في النقل.

الهُف من الدراسة: تقييم نمط ومستوى شدة الإصابة والعوامل المرثبطة بالخطورة بين ضحايا حوادث المركبات ثلاثية العجلات الذين أدخلوا بمستشفيات جامعة المنوفية في الفترة من الأول من يناير إلى نهاية

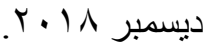

مواد طرق البحث: أجريت دراسة مستقبلية مدتها عام و احد على OY ضحية تعرضو الحو ادث المركبات ثلاثية العجلات. وتم جمع بيانات عن الضحايا بما في ذلك الييانات الثخصية (العمر والجنس و الإقامة ، و بيانات الحو ادث (طبيعة الحادث ونوع الإصابة ونوع الضحية)؛ البيانات السريرية (منطقة الجسم المصابة ، نوع و شدة الإصابة ، طرق العلاج و النتيجة). كما حُسبت درجة شدة الإصابة وصنفت الحالات وفقاً لذلك على أنها تعاني من إصابة طفيفة و إصابة كبيرة.

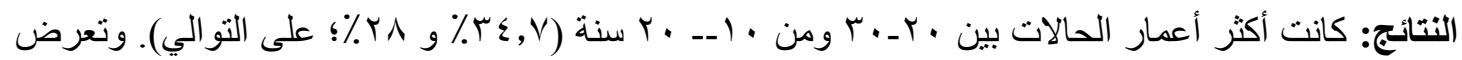

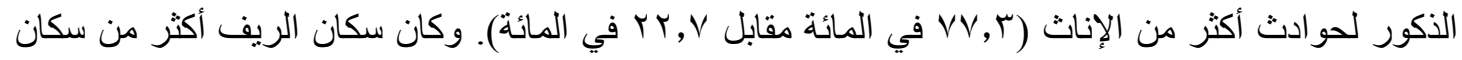

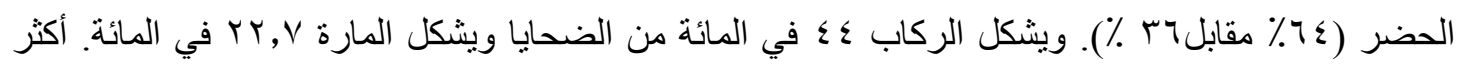

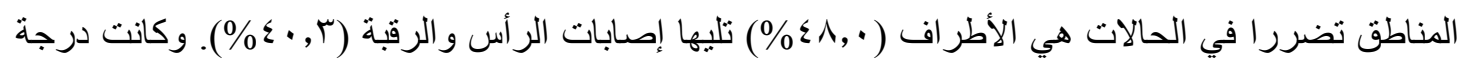

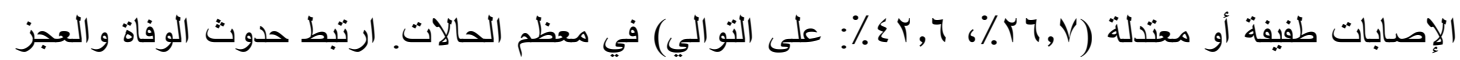
بشكل كبير بدرجة الإصابات البالغة .

الإستتتاجات: سادت الإصابات الطفيفة إلى المتوسطة في الحوادث المتعلقة بالمركبات ثلاثية العجلات، و وارتبطت الإصابات الثديدة بالضحايا الصغار وأولئك الذين يعانون من إصابات في الرأس والرقبة و الذين يحتاجون إلى فترة طويلة من الإقامة في المستثفى و العلاج الجر احي ودخول وحدة العناية المركزة. التوصيات: نوصي الدراسة بإضافة حز ام الأمان إلى تصميم المركبات ثلاثية العجلات لكل من الر اكب و السائق مع تركيب أبو اب لهذه المركبات. أيضا ضرورة وضع لوائح صارمة لالز ام سائقي المركبات ثلاثية العجلات باستخر اج رخصة قيادة واتباع الحد الأقصى للسر عة للحد من خطر هذة الحو ادث. 